\title{
Manajemen Mutu Lembaga Pendidikan Berprestasi Pada Madrasah Ibtidaiyah
}

\author{
Sri Setyo $^{1 *)}$, Mudhofir $^{2)}$, Siti Choiriyah ${ }^{3)}$ \\ ${ }^{1,2,3}$ Institut Agama Islam Negeri (IAIN) Surakarta \\ *Email korespondensi: srisetyo@gmail.com
}

\begin{abstract}
This study aims to determine the quality management of outstanding educational institutions at Madrasah Ibtidaiyah, where this research is conducted at Madrasah Ibtidaiyah Negeri 6 Sukoharjo. This research was conducted on quality planning at Madrasah Ibtidaiyah Negeri (MIN) 6 Sukoharjo in realizing outstanding educational institutions, reviewing and describing in more depth the implementation of quality at Madrasah Ibtidaiyah Negeri (MIN) 6 Sukoharjo in realizing educational institutions with achievement, and assessing and describing in depth more in-depth about evaluating the quality at Madrasah Ibtidaiyah Negeri (MIN) 6 Sukoharjo in realizing outstanding educational institutions. The methodology in this study uses a qualitative approach. Data collection techniques in this study are by observation, interviews and documentation. The method used to check the validity of the data is method triangulation, namely by using various methods as a consideration. The results showed that: 1). Planning: establishing the vision and mission as quality guidelines, commitment to the implementation of national standard schools, a comfortable and good service process, increasing the quality of students' input, using quality references set by the government, quality planning in management reviews, improving the quality of inputs in Madrasah Ibtidaiyah Negeri (MIN) 6 Sukoharjo is the result of a sustainable program, improving services through the distribution of questionnaires, the existence of a quality assurance design or design at Madrasah Ibtidaiyah Negeri (MIN) 6 Sukoharjo as a line and reference in order to maintain and improve educational institutions with achievement. 2). Implementation: implementing a national standard curriculum and a typical school curriculum, educators and education personnel have a minimum qualification of a bachelor, there is satisfaction from students and parents / guardians of students as users, graduates are 100\% and equipped with expertise, the presence of representative infrastructure, transparent education management, very good and very close relations between the school and the community, the existence of special services for supporting learning activities. 3). Evaluation: conducting self-evaluation of school performance based on accountability, transparency, efficiency and effectiveness, evaluating the learning process at the end of each semester, compiling reports from the results of self-evaluations that have been carried out, compiling priority scales of various activities and follow-up programs on the results of self-evaluation the results of the analysis as a construction of improvements carried out gradually and continuously in realizing outstanding educational institutions.
\end{abstract}

Keywords: quality management, outstanding educational institutions, Madrasah Ibtidaiyah

Saran sitasi: Setyo, S., Mudhofir., \& Choiriyah, S. (2021). Manajemen Mutu Lembaga Pendidikan Berprestasi Pada Madrasah Ibtidaiyah. Jurnal Ilmiah Ekonomi Islam, 7(01), 266-274. doi:http://dx.doi.org/10.29040/jiei.v7i1.2215

DOI: http://dx.doi.org/10.29040/jiei.v7i1.2215

\section{PENDAHULUAN}

Pendidikan dalam konsep pengembangan masyarakat merupakan dinamisasi dalam pengembangan manusia yang beradab. Pendidikan tidak hanya terbatas berperan pada pengalihan ilmu pengetahuan (Transfer of knowledge) saja, namun juga berfungsi mengembangkan kemampuan dan membentuk watak serta peradaban bangsa yang bermartabat dalam rangka mencerdaskan kehidupan bangsa, bertujuan untuk berkembangnya potensi peserta didik/siswa agar menjadi manusia yang beriman dan bertaqwa kepada Tuhan Yang Maha Esa, berakhlak mulia, sehat, berilmu, cakap, kreatif, mandiri, dan menjadi warga negara yang demokratis serta bertanggung jawab. 
Dari fungsi dan tujuan pendidikan di atas diharapkan manusia Indonesia adalah manusia yang seimbang antara kecerdasan segi kognitif, afektif, dan psikomotor, dan dalam pencapaian tujuan pendidikan nasional, dunia pendidikan nasional dihadapkan pada satu masalah besar yakni peningkatan mutu dan relevansi pendidikan. Masalah ini menjadi fokus yang paling penting dalam pembangunan pendidikan nasional.

Pendidikan mempengaruhi secara penuh pertumbuhan ekonomi suatu bangsa. Dalam peningkatan kualitas manusia Indonesia, pemerintah tidak merupakan satu sistem yang lepas dengan pihak swasta dan masyarakat. Hubungan pemerintah, masyarakat dan swasta merupakan hubungan yang tidak terpisahkan dalam peranannya dalam meningkatkan pemerataan dan mutu pendidikan.(Nanang Fattah, 2000).

Untuk menjamin mutu dan kualitas pendidikan diperlukan perhatian yang serius, baik oleh penyelenggara pendidikan, pemerintah, maupun masyarakat. Sebab dalam sistem pendidikan nasional sekarang ini, konsentrasi terhadap mutu dan kualitas bukan semata-mata tanggung jawab Pendidikan Tinggi dan pemerintah, tetapi merupakan sinergi antara berbagai komponen termasuk masyarakat. Untuk melaksanakan penjaminan mutu tersebut, diperlukan kegiatan yang sistematis dan terencana dalam bentuk manajemen mutu. Manajemen mutu dalam pendidikan merupakan cara dalam mengatur semua sumber daya pendidikan, yang diarahkan agar semua orang yang terlibat di dalamnya melaksanakan tugas dengan penuh semangat dan berpartisipasi dalam perbaikan pelaksanaan pekerjaan sehingga menghasilkan jasa yang sesuai bahkan melebihi harapan.(Sri Winarsih, 2017).

Memasuki era reformasi, pemerintah Indonesia sesungguhnya telah mencanangkan grand design peningkatan mutu pendidikan. Rancangan mutu berkelanjutan dimulai dengan perumusan regulasi dalam bentuk Undang- Undang, Peraturan Pemerintah, Peraturan Presiden, dll. Diantaranya dapat disebutkan: (1) UU No. 20 Tahun 2003 tentang Sistem Pendidikan Nasional, (2) UU No. 14 Tahun 2005 tentang Guru dan Dosen, (3) UU No. 12 Tahun 2012 tentang Pendidikan Tinggi, (4) PP No. 19 Tahun 2005 tentang Standar Nasional Pendidikan dan perubahannya pada No. 32 Tahun 2013, (5) PP No. 74 Tahun 2008 tentang Guru, (6) PP No. 37 Tahun 2009 tentangg Dosen, (7) Peraturan Presiden No. 8 Tahun 2012 tentang Kerangka Kualifikasi Nasional Indonesia, (8) PP No. 49 tahun 2014 tetang Standar Nasional Pendidikan Tinggi. Dalam regulasi- regulasi tersebut nampak adanya upaya sistematis pemerintah mengoptimalkan pemberdayaan tenaga pendidik dan sekolah melalui proses sertifikasi tenaga pendidik dan pengawas, akreditasi lembaga pendidikan, standarisasi mutu, peningkatan gaji dan kesejahteraan guru, dosen, pengawas.

Menurut Munif Chatib (2011) bahwa sekolahsekolah di Indonesia memiliki empat kategori: (1) Sekolah yang tidak mati dan tidak hidup, dengan ciriciri: tidak mendapat kepercayaan masyarakat, jumah peserta didik sedikit, kualitas guru rendah, manajemen sekolah aburadul; (2) Sekolah tumbuh, dengan ciriciri: kepercayaan masyarakat sangat besar, peserta didik mendaftar lebih banyak daripada kapasistas sekolah, masih berada pada jenjang tertentu, misalnya kelas yang tinggi baru kelas $3 \mathrm{SD}$, membutuhkan rekruitan guru baru setiap tahun, menajemen sekolah masih mencari bentuk; (3) sekolah bermanajemen internasonal, dengan ciri-ciri: kepercayaan masyarakat sangat besar, peserta didik mendaftar lebih besar daripada kapasitas sekolah, fokus pada peningkatan kualitas guru, manajemen sekolah sudah stabil; dan (4) sekolah baru akan dibangun, dengan ciri-ciri: penyelenggara sekolah baru punya niat membangun sekolah (bangunan fisik) dan perekruitan guru.

Regulasi dan potret sekolah sebagaimana digambarkan di atas, tidak lain membicarakan tentang mutu pengelola, terutama guru sebagai unjung tombak peningkatan mutu pendidikan. Ceritera kemanjuan negara-negara di dunia dimulai dengan upaya peningkatan kualitas guru. Jepang dan Korea Selata di Asia dan negera-negara Eropa adalah contoh nyata kemajuan dalam beragam sektor yang berawal dari upaya meningkatkan mutu guru. Kerena itu harus diakui bahwa kualitas guru adalah kunci utama kemajuan bangsa (Baswedan dalam Chatib, 2011). Implementasi regulasi bidang pendidikan di Indonesia belum menunjukkan hasil yang menggembirakan. Kompetensi guru masih harus mendapat perhatian serius dari pemerintah dan elemen masyarakat. Uji Kompetensi Guru (UKG), khususnya kompetensi profesional dan pedagogik beberapa tahun terakhir belum menunjukkan hasil optimal.

Sekolah yang berorientasi ke masa depan dimulai dengan perumusan visi, misi, dan tujuan. Menurut 


\section{Jurnal Ilmiah Ekonomi Islam, 7(01), 2021, 268}

Iryanto (2008) hidup yang berorientasi ke masa depan dimiliki oleh peribadi yang memiliki ciri-ciri seperti proaktif terhadap perubahan, memiliki visi hidup yang smart, akrab dengan pengetahuan dan teknologi, memiliki tiga prinsip dasar kehidupan, yakni ada (being), aktualisasi (actualization), menjadi (becoming), memiliki motivasi menjadi yang terbaik, kreatif, dan terbesar.

Charles Hoy dalam bukunya Improving Quality in Education, merumuskan kualitas pendidikan adalah evaluasi dari proses mendidik yang meningkatkan kebutuhan untuk mencapai dan mengembangkan bakat siswa dalam suatu proses, dan pada saat yang sama memenuhi standar akuntabilitas yang ditetapkan oleh klien yang membiayai proses atau output dari proses pendidikan. (Charles, at.all. 2000). Sedangkan Menurut Hoy dan Miskel, sekolah bermutu adalah sekolah yang efektif, yang terdiri dari tatanan input, proses, dan out-put. Dengan demikian, madrasah bermutu adalah madrasah yang menerapkan rumusan sekolah efektif. Secara out- put, hasil yang peroleh dari madrasah efektif adalah: Pertama, dari aspek siswa, lulusan yang dihasilkan adalah siswa yang memiliki prestasi akademik yang unggul, punya kreativitas, percaya diri, aspiratif, tidak ragu untuk mengemukakan pendapat, memiliki ekspektasi yang tinggi, selalu hadir dalam kegiatan, dan memiliki tingkat kelulusan yang tinggi, dan sebaliknya, angka putus sekolah tidak ada sama sekali atau nol persen. (Hoy, Wayne K., dan Cecil G. Miskel. 2008).

Selain berprestasi tinggi, siswa juga memiliki karakter yang menjadi ciri khas madrasah. Imam Ghazali, seorang pemikir Islam memberikan tuntunan budi pekerti yang luhur yang dapat menjadi bagian dari karakter siswa. Siswa harus didorong untuk memupuk perilaku baik berdasarkan sistem suara seperti nilai-nilai sebagai mengatakan kebenaran, iman, kejujuran, kerendahan hati dan menghindari kesombongan. Al-Ghazali menekankan bahwa pendidikan adalah proses total yang harus merawat setiap aspek manusia, intelektual, psikologis, social, fisik dan spiritual. Pengajaran harus dilakukan secara sensitif, sehingga perbedaan antara siswa diakui dan mereka dibantu untuk berkembang sesuai kemampuan dan kepentingan mereka sendiri.( Joy A Palmer, 2001).

Pada jenjang pendidikan madrasah, kompetensi yang diharapkan dari siswa lulusannya adalah: Mampu membaca al-quran dan memahaminya, berakhlak mulia, memahami fikih Islam, terbiasa melakukan ibadah sehari-hari, mampu menyampaikan ceramah sederhana, dan mampu mengambil i'tibar atau pelajaran dari sejarah Islam. Selain itu, siswa juga diharapkan mampu: (1) Meningkatkan keimanan dan ketakwaan yang telah ditanamkan dalam keluarga, (2) Menyalurkan bakat dan minatnya serta mengembangkannya secara optimal, (3) Memperbaiki kekurangan dan kelemahannya dalam mengamalkan ajaran Islam, (4) Menangkal pengaruh negatif kepercayaan atau budaya lain yang membahayakan keyakinan, (5) Menyesuaikan diri dengan lingkungan fisik dan sosial agar sejalan dengan ajaran Islam, (6) Menjadikan Islam sebagai pedoman hidup untuk mencapai kebahagiaan dunia dan akhirat, (7) Mampu memahami Islam secara menyeluruh sesuai dengan daya serap siswa dan waktu yang dimilikinya.(Muhaimin, 2005).

Kedua, dari aspek guru, sekolah yang bermutu memperhatikan kepuasan kerja guru, angka absen nol persen, dan pergantian atau memberikan amanah kepada guru untuk tugas-tugas tertentu. Komariah dan Triatna, mengemukakan bahwa guru merupakan ujung tombak pendidikan. Keberadaan guru menjadi aspek penting bagi keberhasilan sekolah, terutama bagi guru yang melaksanakan fungsi mengajarnya dengan penuh makna (purposeful teaching). (Aan Komariah dan Cepi Triatna, 2006). Maksudnya guru sangat kompeten di bidangnya bekerja secara professional dan menjadi seorang yang serba bisa dan memiliki harapan tinggi terhadap profesi dan siswanya (high expectation all round). Guru menjadi seorang komunikator yang menanamkan harapan kepada siswanya (comunicating expectation) dan guru adalah seorang seorang yang cerdas yang senantiasa bergelut dengan ilmu pengetahuan serta menyenangi tantangan intelektual.

Pada konteks madrasah, beberapa sifat yang harus dimiliki guru antara lain: Pendidik harus memiliki keteladanan (uswah hasanah) dalam sifat: (1) Tujuan, tingkah laku dan pola pikir guru bersifat rabbani yaitu hendaknya selalu bersandar kepada Rabb dengan menaati-Nya, mengabdi kepada-Nya, mengikuti syariat- Nya dan mengenal sifat-sifat-Nya. (2) Hendaknya guru seorang yang ikhlas.(3) Guru bersabar dalam mengajarkan berbagai pengetahuan kepada anak-anak. (4) Jujur dalam menyampaikan apa yang diserukannya.(5) senantiasa membekali diri dengan ilmu dan kesediaan membiasakan diri untuk terus mengkajinya. Guru berpengetahuan luas dengan ilmu yang dikajinya. (6) Hendaknya guru mampu 
menggunakan berbagai metode mengajar secara bervariasi. Penguasaan ilmu saja belum cukup, karena tidak setiap orang berilmu mampu mentransformasikannya kepada anak didik. (7) Guru mampu mengelola siswa, tegas dalam bertindak serta meletakkan berbagai perkara secara proporsional. (8) Mempelajari kehidupan psikis para pelajar selaras dengan masa perkembangannya ketika mengajar mereka, sehingga dia dapat memperlakukan mereka sesuai dengan kemampuan akal dan kesiapan psikis mereka. (9) Tanggap terhadap berbagai kondisi dan perkembangan dunia yang mempengaruhi jiwa, keyakinan dan pola berpikir angkatan muda. (10) Seorang guru dituntut memiliki sifat adil terhadap seluruh anak didiknya (An-Nahlawi, Abdurrahman, 2004).

Murid memandang guru sebagai teladan utama bagi mereka. Mereka akan mengikuti jejak akhlak, ilmu, kecerdasan, keutamaan dan semua gerak gerik gurunya. Maka seyogyanya guru menyesuaikan diri dengan prinsip dan nilai yang mereka ajarkan. Guru merupakan gambaran hidup yang memantulkan keutamaan tingkah laku yang sebenarnya sehingga murid dapat membiasakan diri dengan contoh tersebut dan sebagai syiar yang harus ditegakkan secara lahir dan batin (Muhammad Abdul Kadir Ahmad, 2008). Sejalan dengan sifat-sifat tersebut, Ahmad Tafsir mengemukakan bahwa guru juga memiliki tugas untuk mengetahui karakter murid- muridnya, meningkatkan keahliannya baik dalam bidang yang diajarkan maupun cara mengajarkannya, dan mengamalkan ilmunya, jangan berbuat berlawanan dengan ilmu yang diajarkannya.(Ahmad Tafsir, 2010).

Ketiga, dari aspek pengelola (administrator), sekolah bermutu juga memperhatikan kepuasan kerja para staf, menyediakan anggaran yang seimbang, dan memiliki staf yang komitmen dan loyalitas kepada madrasah. Keempat, dari luar madrasah, masyarakat memberikan citra yang positif terhadap sekolah atau madrasah, hingga menjadikannya pilihan utama untuk mempercayakan pendidikan putra putri mereka.

Pada konteks ini, untuk mempercepat peningkatan mutu madrasah secara efektif, diperlukan pemahaman terhadap hakekat dan problematika madrasah. Madrasah sebenarnya merupakan model lembaga pendidikan yang ideal karena menawarkan keseimbangan hidup: iman-takwa (imtak) dan ilmu pengetahuan- teknologi (iptek). Di samping itu, sebagai lembaga pendidikan berbasis agama dan memiliki akar budaya yang kokoh pada masyarakat, madrasah memiliki basis sosial dan daya tahan yang luar biasa. Maslowski menyebutkan bahwa inti dari budaya sekolah adalah para guru. Guru dapat mempertimbangkan, hingga menentukan hal-hal yang baik atau hal-hak buruk yang terjadi pada sekolah dan selanjutnya menginternalisasikannya kepada seluruh warga belajar di sekolah (Maslowski, 2006).

Oleh karena itu, Pendidikan Islam memiliki tujuan mengantarkan ummat menjadi pribadi muslim yang berkualitas dalam menjalankan tugas hidupnya sesuai dengan maksud diciptakan ke bumi Sang Khaliq, yaitu sebagai 'abdillaah (Depag RI, 2009) dan khalifatullaah fi al-ard (Depag RI, 2009). Penguatan dan pendalaman ilmu pengetahuan lewat pendidikan diharapkan bisa menjadi bekal yang efektif dan tepat dalam mewujudkan kesuksesan dan kemuliaannya di dunia hingga akhirat.

Penguasaan terhadap manajerial, kemampuan dan orientasi merencanakan, mengorganisasikan, mengkomunikasikan, memotivasi, mengarahkan mengawasi yang dilakukan terus menrus merupakan upaya peningkatan mutu madrasah/sekolah. Mutu merupakan sesuatu yang ideal dan tidak dapat dikompromikan, maka mutu sekolah/madrasah selalu memenuhi standar tertinggi yang tidak dapat diungguli, seperti kebaikan, keindahan, kebenaran. Untuk memuaskan pemakai lulusan sekolah/madrasah maka sekolah/madrasah harus memahami bahwa proses pendidikan merupakan suatu peningkatan terus menerus yang dimulai dari rangkaian siklus mulai sejak adanya ide-ide yang menghasilkan lulusan yang bermutu, pengembangan kurikulum, serta proses pembelajaran ikut bertanggung jawab. Oleh karena itu, untuk memberikan kepuasan pada pelangan utama sekolah/madrasah, dengan memperbaiki kinerja, memperbaiki kualitas yang dimulai dari sebuah komitmen untuk melakukan perubahan oleh seluruh komponen sekolah/madrasah. Dalam pemanfaatan manajemen mutu terpadu konteks pendidikan strategi yang dikembangkan adalah memposisikan lembaga pendidikan sebagai lembaga jasa atau disebut juga industry jasa, yaitu lembaga yang memberikan pelayanan sesuai apa yang dibutuhkan oleh pelanggan. Jasa atau layanan yang dibutuhkan oleh pelanggan adalah yang bermutu dan memuaskan. Oleh karena itulah dibutuhkan konsep manajemen yang mampu memberdayakan institusi pendidikan agar berprestasi. Sebagai muara utama manajemen pendidikan mutu terpadu berpijak pada kepuasan pelanggan. Adapun pelanggan dapat dibedakan 


\section{Jurnal Ilmiah Ekonomi Islam, 7(01), 2021, 270}

menjadi dua bagian, yaitu: (internal customer) dalam dan (external customer) luar. Pada konteks pendidikan internal customer adalah pengelola institusi: kepala sekolah, guru, dan staf. Sedangkan external custumer adalah masyarakat, dunia industry, dan pemerintah. Kualitas manajerial yang menjadikan lembaga pendidikan berprestasi yang pada puncaknya antara internal customer dan external customer terwujud adanya penerimaan kepuasan atas layanannya.

Madrasah Ibtidaiyah Negeri 6 Sukoharjo yang berada di Jl. Nglawu, Dusun I, Telukan, Kec. Grogol, Kabupaten Sukoharjo, Jawa Tengah merupakan madrasah ibtidaiyah negeri yang memiliki kualitas yang sangat baik sekaligus menjadi rujukan bagi madrasah-madrasah ibtidaiyah yang lain dalam melakukan studi banding yang berkaitan dengan manajemen mutu lembaga pendidikan berprestasi. Keadaan seperti itu tentunya sangat menarik untuk dilakukan riset atau penelitian dalam rangka mengkaji dan mendeskripsikan secara lebih mendalam terhadap perencanaan mutu pada Madrasah Ibtidaiyah Negeri (MIN) 6 Sukoharjo dalam mewujudkan lembaga pendidikan berprestasi, mengkaji dan mendeskripsikan secara lebih mendalam terhadap pelaksanaan mutu pada Madrasah Ibtidaiyah Negeri (MIN) 6 Sukoharjo dalam mewujudkan lembaga pendidikan berprestasi, dan mengkaji serta mendeskripsikan secara lebih mendalam terhadap pengevaluasian mutu pada Madrasah Ibtidaiyah Negeri (MIN) 6 Sukoharjo dalam mewujudkan lembaga pendidikan berprestasi.

Berdasarkan latar belakang masalah di atas, peneliti tertarik melakukan penelitian dengan mengangkat tema "Manajemen Mutu Lembaga Pendidikan Berprestasi Pada Madrasah Ibtidaiyah" dengan obyek penelitian di Madrasah Ibtidaiyah Negeri 6 Sukoharjo.

\section{KAJIAN TEORI}

\subsection{Manajemen Mutu}

Manajemen merupakan suatu rangkaian kegiatan kepengurusan, ketatalaksanaan penggunaan sumber daya untuk mencapai sasaran atau tujuan pokok yang telah ditentukan dengan menggunakan orang-orang pelaksana dalam suatu hubungan kerjasama. Manajemen adalah suatu rangkaian tindakan dengan maksud untuk mencapai hubungan kerjasama yang rasional dalam suatu sistem administrasi (Fathul Jannah, 2015). Inti dari tujuan dan manfaat manajemen dalam penyelenggaraan pendidikan adalah untuk mencapai dan meningkatkan efektivitas, efisiensi dan produktivitas kerja dalam mencapai tujuan pendidikan yang diinginkan. Efektivitas adalah suatu keadaan yang mengandung pengertian mengenai teriadinya efek atau hasil yang dikehendaki. Jadi suatu pekerjaan dikatakan efektif, jika pekerjaan tersebut mencapai atau tujuan yang telah ditentukan. Efektivitas umumnya merujuk pada pencapaian tujuan.

Sedangkan efisiensi adalah suatu pengertian yang menggambarkan perbandingan terbaik antara usaha dengan hasilnya. Perbandingan ini dapat dilihat dari dua hal, pertama dari segi hasil yaitu pekerjaan dikatakan efisien jika dengan usaha tertentu memberikan hasil maksimal, baik mengenai mutu maupun jumlah. Kedua dari segi usaha, pekerjaan dikatakan efisien jika suatu hasil tertentu tercapai dengan suatu usaha yang minimal. Efisien merujuk pada proses dengan pendayagunaan sumber daya, biaya dan lain-lain. Dengan demikian, manajemen pendidikan bertujuan untuk memberikan kemudahan, cara agar suatu pengelolaan dapat berjalan dengan baik. Oleh karena itu tujuan dapat disebut juga hasil dari manajemen tersebut.

Mutu atau kualitas adalah gambaran dan karakteristik menyeluruh dari barang atau jasa yang menunjukkan kemampuannya dalam memuaskan kebutuhan yang diharapkan atau yang tersirat. (Rohiat, 2010). Umaedi (2006) dalam manajemen peningkatan mutu berbasis sekolah/madrasah mendefinisikan mutu sebagai sifat-sifat yang dimiliki suatu benda atau barang atau jasa yang secara keseluruhan memberi rasa puas kepada penerima atau penggunanya karena telah sesuai atau melebihi apa yang dibutuhkan dan diharapkan pelanggannya. Manajemen mutu menjadi suatu keharusan dalam pembenahan Lembaga pendidikan. Semua jenis kegiatan manajemen yang secara langsung maupun tidak langsung terlibat dalam pengelolaan lembaga pendidikan harus senantiasa diarahkan dan berorientasi pada pencapaian mutu. Mutu produk pendidikan akan dipengaruhi oleh sejauh mana lembaga mampu mengelola seluruh potensi secara optimal mulai dari tenaga kependidikan, peserta didik, proses pembelajaran, sarana pendidikan, keuangan dan termasuk hubungannya dengan masyarakat. Dalam hal ini, sekolah harus mampu merubah paradigma baru pendidikan yang berorientasi pada mutu semua aktifitas yang 


\section{Jurnal Ilmiah Ekonomi Islam, 7(01), 2021, 271}

berinteraksi didalamnya, seluruhnya mengarah pencapaian pada mutu (Hendro Widodo, 2018).

\subsection{Lembaga Pendidikan Berprestasi}

Tingkat pendidikan adalah tahapan pendidikan yang ditetapkan berdasarkan tingkat perkembangan peserta didik, tujuan yang akan dicapai dan kemauan yang dikembangkan. Tingkat pendidikan berpengaruh terhadap perubahan sikap dan perilaku hidup sehat. Tingkat pendidikan yang lebih tinggi akan memudahkan seseorang atau masyarakat untuk menyerap informasi dan mengimplementasikannya dalam perilaku dan gaya hidup sehari- hari, khususnya dalam hal kesehatan(Suhardjo, 2007).

Lembaga pendidikan formal adalah semua bentuk pendidikan yang diadakan di sekolah atau tempat tertentu, teratur, sistematis, mempunyai jenjang dan dalam kurun waktu tertentu, serta berlangsung mulai dari Taman Kanak-kanak, sampai perguruan tinggi. Berdasarkan aturan resmi yang telah ditetapkan. Pendidikan formal merupakan tangga kedua setelah pendidikan informal, karena pendidikan formal wadah yang membantu tugas-tugas yang dibebankan oleh pendidikan informal tersebut, baik dalam hal pengisian nilai-nilai kognitif maupun psikomotorik, bahkan sikap efektif pun sangat penting sekali. Disamping setiap peserta didik atau anak didik itu mendapat legalitas formal yang sangat dibutuhkan manakala setiap anak akan formal itu mempunyai program dan rencana yang terpadu dan mempunyai aturan yang tetap dan ketat serta mempunyai jenjangjenjang. Jadi pendidikan di sekolah atau pendidikan formal adalah pendidikan yang diperoleh seseorang di sekolah secara teratur, sistematis, bertingkat dan dengan mengikuti syarat-syarat yang jelas dan ketat mulai dari taman kanak-kanak sampai perguruan tinggi (Muri Yusuf, 2006).

Pendidikan nonformal adalah merupakan pendidikan (pada umumnya) di luar sekolah yang secara potensial dapat membantu, dan menggantikan pendidikan formal dalam aspek-aspek tertentu, seperti pendidikan dasar atau keterampilan kejuruan khusus (Muri Yusuf, 2006). Dalam proses pelaksanaannya, pendidikan nonformal disesuaikan dengan keadaan peserta didiknya agar dapat memperoleh hasil yang memuaskan atau yang lebih baik untuk menjadikan seseorang mempunyai ilmu pengetahuan yang paripurna. Selain ilmu yang bersumber dari pendidikan informal dibutuhkan pendidikan nonformal yang diterima di luar sekolah maupun di luar rumah. Seseorang tidak dapat dipisahkan dari masyarakat dimanapun seseorang itu berada, dalam lingkungan masyarakat seseorang itu bergaul dan berinteraksi secara timbal balik yang pada gilirannya akan dapat mempengaruhi dirinya, sehingga dengan hal itu pula seseorang itu dapat menggambarkan kepribadiannya menjadi orang yang mempunyai seperangkat ilmu pengetahuan.

Pendidikan informal adalah merupakan suatu proses yang sesungguhnya terjadi seumur hidup yang karenanya tiap- tiap individu memperoleh sikap, nilai, keterampilan dan pengetahuan dari pengalaman sehari-hari dan pengaruh lingkungannya dari famili atau keluarga dan tetangga, dari pekerjaan dan permainan, dari pasar, perpustakaan dan media massa. (Muri Yusuf, 2006). Pelaksanaan pendidikan informal terdapat dalam suatu keluarga. Proses pelaksanaannya berlangsung sejak seseorang itu dilahirkan. Dengan demikian kehadiran orang tua dalam keluarga sangat penting sekali, karena ketika anak lahir dan dalam sepanjang kehidupannya selalu membutuhkan bimbingan dan pengarahan. Sebagaimana yang dijelaskan oleh Chalidjah Hasan : "Kehadiran orang tua dalam keluarga menjadi sangat penting untuk menentukan masa depan anak, khususnya masa depan kehidupan anak, dalam dimensi psikologi seorang anak memang membutuhkan pembimbing dan pembina guna mengarahkan perkembangan jiwanya (Calidjah Hasan, 2004).

Sutratinah Tirtonegoro mengartikan prestasi belajar sebagai penilaian hasil usaha kegiatan belajar yang dinyatakan dalam bentuk simbol, angka, huruf, maupun kalimat yang dapat mencerminkan hasil yang sudah dicapai oleh setiap anak dalam periode tertentu(Sutratinah Tirtonegoro, 2001). Prestasi belajar adalah hasil yang dicapai oleh siswa selama proses belajar mengajar dalam kurun waktu tertentu. Hasil pengukuran dari belajar tersebut diwujudkan dalam bentuk angka, huruf, simbol, maupun kalimat yang menyatakan keberhasilan siswa selama proses pembelajaran. Prestasi belajar seorang murid dapat diketahui dengan mengadakan proses penilaian atau pengukuran melalui kegiatan evaluasi. Alat evaluasi dalam pengukuran prestasi belajar adalah tes yang telah disusun dengan baik supaya hasilnya benarbenar dapat mengukur kemampuan seorang murid. Prestasi belajar yang dimaksudkan ialah hasil (penguasaan) yang dicapai oleh siswa dalam bidang 


\section{Jurnal Ilmiah Ekonomi Islam, 7(01), 2021, 272}

studi tertentu setelah mengikuti proses belajar mengajar di suatu sekolah.

\subsection{Madrasah Ibtidaiyah Negeri}

Madrasah berasal dari akar kata darrasa, yaitu belajar, sedangkan madrasah berarti tempat belajar atau sekolah formal. Madrasah menurut orang awam adalah lembaga pendidikan tingkat dasar dan menengah yang mengajarkan agama Islam saja, perpaduan antara ilmu agama Islam dan ilmu umum, maupun ilmu berbasis ajaran Islam (Nata, 2001). Madrasah Ibtidaiyah yang disingkat MI memiliki enam tingkat atau jenjang sekolah dasar adalah satuan pendidikan formal yang menyelenggarakan pendidikan umum yang memiliki kekhasan agama Islam. (Peraturan mentri agama RI no 60 tahun 2015). Madrasah Ibtidaiyah (MI) sama halnya seperti sekolah dasar pada umumnya yaitu terdiri dari enam kelas atau jenjang namun perbedaan yang ada pada sekolah biasa yaitu sekolah dasar pada umumnya untuk pelajaran agama tidaklah spesifik atau mendalam jika madrasah maka untuk pelajaran keagamaannya mendalam. Seperti aqidah akhlak, bahasa arab, al-quran hadis, ski dan fikih. Jika di sekolah umum hanya PAI atau agama lainnya.

Madrasah mengalami pengintegrasian saat lahirnya UUSPN No. 2/1989 tentang Sistem Pendidikan Nasional yang mencakup ketentuan semua jalur dan jenis pendidikan. Baik jalur sekolah dan luar sekolah, serta meliputi jenis pendidikan akademik, pendidikan profesional, pendidikan kejuruan, dan pendidikan keagamaan (Undang-undang Sistem Pendidikan Nasional, 1994). UU No.2 Tahun 1989 tentang Sistem Pendidikan Nasional ini sekaligus menggantikan UU No. 4 Tahun 1950 dan UU No. 12 Tahun 1945. Undang-undang berisi penegasan definitif tentang madrasah yang lebih operasional dan dimasukkan dalam kategori sekolah tanpa menghilangkan karakter keagamaannya. Melalui upaya ini madrasah berkembang secara terpadu dalam sistem pendidikan (Maksum, 2016).

Madrasah negeri adalah madrasah yang pengadaannya dilaksanakan oleh Negara. Madrasah negeri memiliki pandangan yang baik dan bagus di kalangan masyarakat. Masyarakat umumnya memandang bahwa madrasah negeri lebih unggul dari madrasah swasta, baik dari segi fasilitas maupun kualitas (Makruf, 2016).

\section{METODOLOGI PENELITIAN}

Penelitian ini menggunakan pendekatan kualitatif. Pendekatan penelitian kualitatif ini, untuk melakukan penelitian yang berkaitan dengan manajemen mutu lembaga pendidikan berprestasi pada Madrasah Ibtidaiyah Negeri 6 Sukoharjo. Jenis penelitian yaitu deskriptif kualitatif. Arikunto (2002) berpendapat bahwa pada umumnya penelitian deskriptif merupakan penelitian non hipotesa, sehingga dalam rangka penelitiannya tidak perlu merumuskan hipotesis. Penelitian dilaksanakan di Madrasah Ibtidaiyah Negeri (MIN) 6 Sukoharjo yang berada di di Jl. Nglawu, Dusun I, Telukan, Kec. Grogol, Kabupaten Sukoharjo, Jawa Tengah. Pemilihan MIN 6 Sukoharjo ini sebagai lokasi penelitian karena mutu dan prestasi dari Madrasah Intidaiyah Negeri 6 Sukoharjo itu sangat menonjol jika dibanding dengan madrasah-madrasah negeri maupun swasta lainnya di Kabupaten Sukoharjo, sesuai dengan konsep teoritik yang ada, hal itu terbukti dari hasil prestasi akademis maupun prestasi dalam berbagai kejuaraan di Madrasah Ibtidaiyah Negeri maupun swasta se Kabupaten Sukoharjo.

Teknik pengumpulan data pada penelitian ini yaitu dengan observasi, wawancara dan dokumentasi. Metode yang digunakan untuk memeriksa keabsahan data adalah dengan triangulasi method yaitu dengan memanfaatkan berbagai metode sebagai pertimbangan. Triangulasi ini dilakukan dengan jalan membandingkan dan mengecek informasi atau data yang diperoleh dari dokumentasi dengan hasil pengamatan dan interview (Moleong, 2014 :330). Triangulasi ini dilakukan dengan; (1) membandingkan data hasil pengamatan dengan data hasil wawancara, (2) membandingkan apa yang dikatakan orang di depan umum dengan yang dikatakan pribadi, (3) membandingkan apa yang dikatakan orang tentang situasi penelitian dengan apa yang didapat selama penelitian, (4) membandingkan keadaan dan perspektif seseorang dengan berbagai pendapat dan pandangan yang lain, dan (5) membandingkan hasil wawancara dengan isi suatu dokumen yang berkaitan.

\section{HASIL PENELITIAN}

4.1. Perencanaan mutu pada Madrasah Ibtidaiyah Negeri (MIN) 6 Sukoharjo dalam mewujudkan lembaga pendidikan berprestasi.

Perencanaan mutu pada Madrasah Ibtidaiyah Negeri (MIN) 6 Sukoharjo dalam mewujudkan lembaga pendidikan berprestasi dimulai dengan 


\section{Jurnal Ilmiah Ekonomi Islam, 7(01), 2021, 273}

menetapkan visi serta misi MIN 6 Sukoharjo sebagai pedoman mutu dalam pelaksanaan kegiatan pendidikan sehari-hari, komitmen terhadap pelaksanaan dan penyelenggaraan sekolah berstandar nasional yang ditetapkan pemerintah, proses pelayanan di Madrasah Ibtidaiyah Negeri (MIN) 6 Sukoharjo yang sangat nyaman, terus melaksanakan peningkatan input kualitas dari peserta didik sehingga mampu bersaing dengan peserta didik sekolah lainnya, menggunakan acuan mutu yang telah ditetapkan oleh pemerintah serta mngembangkan acuan mutu tersebut sehingga acuan mutu di Madrasah Ibtidaiyah Negeri (MIN) 6 Sukoharjo di atas standar rata-rata, adanya perencanaan mutu pada tinjauan pada tingkat manajemen Madrasah Ibtidaiyah Negeri (MIN) 6 Sukoharjo, peningkatan mutu input sekolah di Madrasah Ibtidaiyah Negeri (MIN) 6 Sukoharjo merupakan hasil dari program berkelanjutan yang telah ditetapkan, meningkatkan pelayanan dengan stakeholder dengan angket atau kuesioner sebagai bahan masukan terhadap pihak-pihak terkait, adanya desain atau rancangan penjaminan mutu di Madrasah Ibtidaiyah Negeri (MIN) 6 Sukoharjo sebagai garis serta acuan dalam rangka menjaga dan meningkatkan lembaga pendidikan berprestasi.

\subsection{Pelaksanaan mutu pada Madrasah Ibtidaiyah} Negeri (MIN) 6 Sukoharjo dalam mewujudkan lembaga pendidikan berprestasi.

Pelaksanaan mutu pada Madrasah Ibtidaiyah Negeri (MIN) 6 Sukoharjo dalam mewujudkan lembaga pendidikan berprestasi dilakukan dengan menerapkan kurikulum nasional serta kurikulum khas yang diterapkan oleh Madrasah Ibtidaiyah Negeri (MIN) 6 Sukoharjo, tenaga pendidik dan tenaga kependidikan di Madrasah Ibtidaiyah Negeri (MIN) 6 Sukoharjo memiliki kualifikasi minimal Sarjana, kemudian khusus tenaga pendidik disarankan untuk melanjutkan ke jenang magister (S2), adanya tingkat kepuasan yang dirasakan oleh para peserta didik serta orang tua atau wali murid sebagai user, lulusan di Madrasah Ibtidaiyah Negeri (MIN) 6 Sukoharjo setiap tahunnya 100\% dan dibekali dengan berbagai skill atau keahlian sesuai minat dan bakat melalui ekstra kurikuler, sarana dan prasarana di Madrasah Ibtidaiyah Negeri (MIN) 6 Sukoharjo yang sangat representatif serta dalam kondisi yang sangat baik, pengelolaan sistem pendidikannya dilakukan dengan transparan dan baik, hubungan pihak sekolah dalam hal ini yaitu Madrasah Ibtidaiyah Negeri (MIN) 6 Sukoharjo dengan masyarakat sangat baik dan sangat dekat, di Madrasah Ibtidaiyah Negeri (MIN) 6 Sukoharjo terdapat layanan spesial berupa fasilitas penunjang proses pembelajaran.

\subsection{Pengevaluasian mutu pada Madrasah Ibtidaiyah} Negeri (MIN) 6 Sukoharjo dalam mewujudkan lembaga pendidikan berprestasi.

Pengevaluasian mutu pada Madrasah Ibtidaiyah Negeri (MIN) 6 Sukoharjo dalam mewujudkan lembaga pendidikan berprestasi dengan melakukan evaluasi diri terhadap kinerja yang telah dilakukan oleh sekolah sebelumnya guna melihat programprogram mana saja yang dinilai perlu dipertahankan dan yang perlu ditingkatkan. Evaluasi diri di Madrasah Ibtidaiyah Negeri (MIN) 6 Sukoharjo berbasis akuntabilitas, transparansi, efisiensi maupun efektivitas, Madrasah Ibtidaiyah Negeri (MIN) 6 Sukoharjo melaksanakan evaluasi secara rutin dalam proses pembelajaran yang dilakukan setiap akhir semester, melakukan kegiatan penyusunan laporan hasil dari kegiatan evaluasi diri, menyusun dan menentukan berbagai skala prioritas kegiatan serta berbagai program tindak lanjut terhadap temuan hasil evaluasi diri Madrasah Ibtidaiyah Negeri (MIN) 6 Sukoharjo dan hasil analisis sebagai kontruksi dari perbaikan yang dilakukan secara bertahap dan berkelanjutan dalam mewujudkan lembaga pendidikan berprestasi.

\section{KESIMPULAN}

Berdasarkan hasil penelitian, maka dapat disimpulkan bahwa manajemen mutu lembaga pendidikan pada Madrasah Ibtidaiyah Negeri (MIN) 6 Sukoharjo yang terdiri dari Perencanaan, pelaksanaan, dan evaluasi. Pada tahap perencanaan memiliki pedoman yang kuat melalui penetapan visi dan misi sebagai pedoman mutu, komitmen terhadap penyelenggaraan sekolah berstandar nasional, proses pelayanan yang nyaman dan baik, peningkatan input kualitas peserta didik, menggunakan acuan mutu yang ditetapkan oleh pemerintah, adanya perencanaan mutu pada tinjauan manajemen. Tahap pelaksanaan dengan menerapkan kurikulum standar nasional dan kurikulum khas sekolah, pendidik dan tenaga 


\section{Jurnal Ilmiah Ekonomi Islam, 7(01), 2021, 274}

kependidikan memiliki kualifikasi minimal sarjana, adanya kepuasan dari para peserta didik dan orang tua/wali murid sebagai user, lulusan di $100 \%$ dan dibekali dengan keahlian, adanya sarana prasarana yang representatif, pengelolaan pendidikan yang transparan, hubungan sekolah dengan masyarakat sangat baik dan sangat dekat, adanya layanan spesial fasilitas penunjang kegiatan pembelajaran. Tahap evaluasi dengan melakukan evaluasi diri terhadap kinerja sekolah yang berbasis akuntabilitas, transparansi, efisiensi maupun efektivitas, melaksanakan evaluasi proses pembelajaran setiap akhir semester, menyusun laporan dari hasil evaluasi diri yang telah dilakukan, menyusun skala prioritas berbagai kegiatan serta program tindak lanjut terhadap hasil evaluasi diri dan hasil analisis sebagai kontruksi dari perbaikan yang dilakukan secara bertahap dan berkelanjutan dalam mewujudkan lembaga pendidikan berprestasi.

\section{DAFTAR PUSTAKA}

Aan K. \& Cepi T. (2006). Visionary Leadership; Menuju Sekolah Efektif. Jakarta: Bumi Aksara.

An-Nahlawi, A. (2004). Pendidikan Islam di Rumah, Sekolah dan Masyarakat, terj. Oleh Shihabuddin, Jakarta: GIP.

Arikunto. (2002). Prosedur Penelitian: Suatu Pendekatan Praktik. Cetakan Kelima belas. Jakarta: Rineka Cipta.

Chatib, M. (2011). Gurunya Manusia: Menjadikan Semua Anak Istimewa dan Semua Anak Juara. Bandung: Kalifa PT Mizan Pustaka.

Charles, T. \& David, R. (2000). "School Effectiveness Research" New York: Falmer Press.

DEPAG RI. (2009). Al-Qur'an dan Tarjemahnya, Surabaya: Mahkota, Disarikan dari surat alDzariat: 56.

Fattah, N. (2000). Ekonomi dan Pembiayaan Pendidikan, Bandung: Remaja Rosdakarya.

Hasan, C. (2004). Dimensi-dimensi Psikologi Pendidikan, Surabaya: al-Ihklas.
Hoy, W. K., dan Cecil G. M. (2008). Educational Administration; Theory, Research, and Practice. McGraw-Hill.

Jannah, F. (2015). Implementasi Model Pembelajaran Kontekstual Dalam Meningkatkan Kualitas Proses Pembelajaran di Sekolah Dasar. -, 1(2), 19-24.

Joy A. P. (2001). Fifty Major Thinkers on Education, London and New York: Routledge.

Makruf, R. B. (2016). "Manajemen Peningkatan Mutu Madrasah Swasta". El.

Maksum, A. (2016). Sosiologi pendidikan. Malang: Madani.

Maslowski, A. (2006). Review of inventories for diagnosing school culture, Journal of Educational Administration, Vol. 44 No. 1, Emerald Group Publishing.

Moleong. Lexy. (2014). Metodologi Penelitian Kualitatif. PT. Remaja Rosdakarya: Bandung.

Muhammad, A. K. A. (2008). Metodologi Pengajaran Agama Islam, Jakarta: Rineka Cipta.

Muhaimin, \& Abdul. M. (2005). Pemikiran Pendidikan Islam. Bandung:Trigenda Karya.

Nata, A. (2009). Perspektif Islam Tentang Strategi Pembelajaran. Jakarta: Kencana.

Rohiat.(2010). Manajemen Sekolah. Bandung: Refika Aditama.

Tafsir, A. (2010). Ilmu Pendidikan dalam Perspektif Islam, Bandung: Remaja Rosdakarya.

Tirtonegoro, S. (2001). Anak Super Normal dan Program Pendidikannya. Jakarta: Bina Aksara.

Umaedi. (2006). Manajemen Peningkatan Mutu Berbasis Sekolah, sebuah Pendekatan Baru dalam Pengelolaan Sekolah untuk Meningkatkan Mutu. Jakarta: Diknas

Winarsih, S. (2017). Kebijakan dan Implementasi Manajemen Pendidikan Jurnal Cendekia Vol.15 No.1.

Yusuf, M. (2006). Metode Penelitian Kuantitatif Kualitatif dan Penelitian Gabungan. Jakarta: Prenadamedia Group. 